\title{
Implementation of Ideological and Political Education in China's Foreign Language Teaching
}

\author{
Qianmei Li \\ College of Foreign Studies \\ Guilin University of Electronic Technology \\ Guilin, China
}

\author{
Ruiyun Zeng \\ College of Foreign Studies \\ Guilin University of Electronic Technology \\ Guilin, China
}

\begin{abstract}
Since the teaching contents in foreign language courses contain culture, values and ideology of foreign countries, it is particularly important to integrate ideological and political education into foreign language teaching. After exploring the implementation approaches to ideological and political education in China's foreign language teaching from four aspects, that is, the construction of teaching system, teaching mode, teaching resource database and learning testing platform, this paper comes to a conclusion that, by implementing the approaches, the great effectiveness of ideological and political education in foreign language teaching can be achieved, and thus the ideologically and politically educational function of "cultivating students' morality and talents" in foreign language teaching can be realized.
\end{abstract}

Keywords-ideological and political education in China's foreign language teaching; cultivating students' morality and talents; implementation approaches

\section{INTRODUCTION}

At a national conference on ideological and political work in China's colleges and universities in December 2016, Xi Jinping, general secretary of the Communist Party of China Central Committee, said that colleges and universities should adhere to the core principle of "cultivating students' morality and talents", integrating ideological and political work into the entire process of education and teaching to fulfill the function of cultivating students in an all-sided way. He also said that to do ideological and political work well, classroom teaching as the main educational channel should be made full use, and all kinds of courses, together with ideological and political theory courses, should be orientated towards ideological and political education, producing a synergy effect. These important remarks are the theoretical development of Marx's Hominology, providing the orientation of education for a new era, that is, ideological and political education should permeate through all curricula. It can also be interpreted as a new educational concept of "ideological and political education in curriculum" with the basic meaning that all curricula in colleges and universities should fulfill the function of knowledge impartment, skill cultivation as well as the function of ideological and political education, cultivating college and university students' outlook on world, life and values. Under the guidance of this concept, China's foreign language teaching should not only play a role of teaching college and university students foreign language knowledge and training their foreign language skills but also play a role of helping college and university students resist the erosion of decaying foreign culture and ideology and enhance their recognition of national culture and core socialist values, and ultimately achieve the goal of "cultivating students' morality and talents" in foreign language teaching.

On the basis of this concept, a number of domestic foreign language scholars have conducted beneficial exploration on ideological and political education in foreign language teaching from multiple dimensions. Three kinds of relevant researches are summarized by the author. The first is to explore the specific implementation approach to integrating ideological and political education into foreign language teaching from the macro perspective, as He Fang et al.[1], Li Ping[2], Fu Ronglin[3], Hu Jun[4], Shi Yujiao[5], Guo Zhibin[6] did. The second is to explore the specific teaching mode for ideological and political education in foreign language teaching from the micro perspective, as Chen Hongmei[7], Wen Zhaorui et al..[8], Wang Dan[9], Yang Gaoyun et al.[10], Zhang Yuling[11], Wang Shuang[12] did. The third is to describe the effects and problems of ideological and political education in foreign language teaching practice in a particular university, as Zhao Mingqi[13], Guo Wei, et al.[14] did. However, reviewing the above researches, there is still a lack of overall-framework research with instructive value for the implementation of ideological and political education in foreign language teaching. Therefore, this study attempts to explore the effective implementation approaches to ideological and political education in foreign language teaching from four aspects, that is, the construction of teaching system, teaching mode, teaching resource database and learning the testing platform.

\section{NECESSITY AND FEASIBILITY For IDEOLOGICAL AND Political EducAtion In Foreign LANGUAGE TEACHING}

\section{A. Necessity}

Under the background of world multi-polarization and economic globalization, the political scheme of capitalist countries' carrying out "peaceful evolution" policy towards socialist countries is becoming increasingly obvious and visible, and the struggle between the two sides is becoming increasingly sharp and complicated. Over a long period of time, the Western capitalist countries have tried to change Chinese young students' ideology by propagandizing the values and ideology of Western capitalism, and distort the values and ideology of China's socialism. Since young students, in the 
foreign language courses. It is very common that, in China's colleges and universities, foreign language curriculum lasts for four semesters, and even longer, with 48-64 average class hours for each semester. Also, in addition to the foreign language majors who are immersing foreign language learning all the time, almost all non-foreign language majors in China's colleges and universities are required to take foreign language courses. Given the advantages of time and participation, foreign language teachers should make full use of them, cultivating students' ideological and political quality cumulatively in foreign language teaching.

\section{IMPLEMENTATION OF IDEOLOGICAL AND POLITICAL EDUCATION IN FOREIGN LANGUAGE TEACHING}

In order to effectively integrate ideological and political education into foreign language teaching, we must make comprehensive adjustment, including the construction of ideological and political teaching system for foreign language curriculum, the construction of ideological and political teaching mode for foreign language curriculum, the construction of ideological and political teaching resource database for foreign language curriculum, and the construction of ideological and political learning testing platform for foreign language curriculum. language educators should guided by Marx’s Hominology and Xi Jinping's speech, constructed a system of ideological and political education in foreign language teaching applicable to China's higher education, infiltrating ideological and political education into foreign language teaching and thus cultivating all-round developed college and university students with sound outlook on world, life and values, and firm belief on communism and socialism with Chinese characteristics.

\section{B. Feasibility}

On the one hand, a wide range of elements about foreign culture, values and ideology are included in China's foreign language teaching contents. Therefore, foreign language teachers can discover the ideologically and politically educational contents from these elements, consciously guiding students to learn from all advanced cultures in developed capitalist countries, resist the pollution of decadent thoughts in the capitalist ideology, and compare the capitalist culture and thoughts with the socialist culture and thoughts in China, so as to strengthen their correct recognition of core socialist values. Besides, the teaching contents in foreign language courses cover many subjects and fields, including natural science, humanities, economy, politics, society, culture and other areas, which can provide abundantly vivid materials for ideological and political education. Therefore, by selecting the contents applicable to both foreign language teaching and ideological and political education and combining them interactively and flexibly, foreign language teachers will achieve the goal of helping students improve their foreign language skills as well as their ideological and political quality.

On the other hand, the foreign language curriculum in China's colleges and universities is characterized by long duration, many periods and wide participation. Specifically, in addition to the foreign language majors who are attending a variety of foreign language courses during their entire college or university learning process, non-foreign language majors also spend a long time and a lot of class hours attending public

\section{A. Constructing the ideological and political teaching system for foreign language curriculum}

Constructing the ideological and political teaching system for foreign language curriculum is to construct a teaching system including four dimensions, namely teaching goal, teaching content, teaching resource database and learning test.

The general teaching goal for ideological and political education in the foreign language curriculum is to help students cultivate core socialist values and resist the Western negative values. Based on this general teaching goal, the specific teaching objective for each course or each activity, according to its specific characteristics, will be set correspondingly. For example, the ideological and political teaching objective for the foreign language reading and writing courses will be set as "being able to get the main idea, understand the main facts and relevant details of the contents reflecting the Chinese and Western values, and perceive the Western negative values and the intentional distortion of China's socialist values in foreign language materials, being able to write a well-organized foreign language essay describing, illustrating and arguing the Chinese and Western values, with explicit central idea, clearcut patriotic stance, accurate and coherent language”.

The general teaching content for ideological and political education in the foreign language curriculum is the foreign language corpus reflecting the Chinese and Western values. Based on this general teaching content, the specific teaching content for each course or each activity, according to its specific characteristics, will be designed correspondingly. For example, the ideological and political teaching content for the English public speaking course will be designed as "the selfintroductory speech showing the talents of successors for socialist construction, the informative speech showing the achievements of socialist construction, the persuasive speech 
"Integrative ideological and political education of praising core socialist values, the commemorative speech honouring communist heroes, the fact, value and policy debate rebutting the Western media's defamation of China, types of supporting materials to defend the correctness of China's way of development, methods of analyzing Western audiences to disseminating China's values, skills of using accurate, clear, vivid and appropriate language to spread China's voice”.

The teaching mode for the ideological and political education in foreign language curriculum is a four-dimensional teaching mode, including "in-class and out-of-class collaborative ideological and political education", "online and offline cooperative ideological and political education”, "comprehensive ideological and political education by listening, speaking, reading, writing and translating”, "integrative ideological and political education of knowledge instruction, skill cultivation and value guidance”.

The learning test for the ideological and political education in foreign language curriculum is to build a three-dimensional testing framework, namely foreign language knowledge, foreign language skills and critical thinking attitude towards values, comprehensively testing college and university students' ideological and political quality after the ideological and political learning practice.

\section{B. Constructing the ideological and political teaching mode for foreign language curriculum}

Constructing the ideological and political teaching mode in foreign language curriculum is to construct a four-dimensional ideological and political teaching mode including "in-class and out-of-class collaborative ideological and political education”, "online and offline cooperative ideological and political education", "comprehensive ideological and political education by listening, speaking, reading, writing and translating”, "integrative ideological and political education of knowledge instruction, skill cultivation and value guidance”.

"In-class and out-of-class collaborative ideological and political education" is to incorporate the ideological and political teaching and activity contents into the daily classroom teaching and the second classroom activities in a targeted and all-round way so that the ideologically and politically educational task will be the routine in foreign language teaching and activities, producing a collaborative effect.

"Online and offline cooperative ideological and political education" is to combine the online ideological and political teaching and activities with the offline ideological and political classroom teaching and activities, with the support of the online platform, new media and other information-based channels, producing a cooperative effect.

"Comprehensive ideological and political education by listening, speaking, reading, writing and translating" is to compile the foreign language materials related to values and ideology in the textbook and the extracurricular foreign language materials related to values and ideology for the ideological and political teaching contents in foreign language listening, speaking, reading, writing and translating courses, through the thoroughly infiltrative teaching, producing a comprehensive effect. knowledge instruction, skill cultivation and value guidance" is to integrate the ideological and political education into foreign language knowledge imparting and foreign language skill cultivating, by instructing students to critically think and judge the Chinese and the Western values in the foreign language teaching activities aimed at ideological and political education, producing an integrative effect.

\section{Constructing the ideological and political teaching resource database for foreign language curriculum}

Constructing the ideological and political teaching resource database for foreign language curriculum is to construct a teaching resource database characterized by diversified types of ideological and political teaching resources that can be used for foreign language curriculum, consisting of the ideological and political materials for foreign language teaching mainly based on the foreign language corpus reflecting the Chinese and Western values, the ideological and political materials for foreign language activities mainly based on the ideological and political topics in foreign language, the ideological and political background knowledge materials in foreign language, the foreign language corpus of socialism with Chinese characteristics, the foreign language corpus of Chinese traditional culture, the teaching courseware for ideological and political education in foreign language curriculum, the learning achievement testing questions for ideological and political education in foreign language curriculum. All the resources are presented in multimodal forms including texts, pictures,

\section{Constructing the ideological and political learning testing platform for foreign language curriculum}

Constructing the ideological and political learning testing platform for foreign language curriculum is to construct a testing platform based on the ideological and political learning achievement testing system, consisting of the ideological and political learning effect testing platform and the foreign language critical thinking skill testing system. It can, from the three dimensions, namely foreign language knowledge, foreign language skills and critical thinking attitude towards values, comprehensively test whether college and university students can utilize the foreign language knowledge they have learned and the foreign language skills they have mastered, with a critical thinking attitude, to understand the fundamental principles of Chinese and Western values and analyze the conflicts between Chinese and Western values reflected in various events, as well as test whether they have the firm confidence in Chinese culture and the correct recognition of core socialist values.

\section{CONCLUSION}

Under the background of world multi-polarization and economic globalization, how to effectively integrate ideological and political education into foreign language teaching has become an important issue confronted by all foreign language educators. This paper explores the implementation approaches to ideological and political education in foreign language teaching from four aspects, that animations, audios, videos, etc. 
[3] Fu Ronglin, "Exploration into the Approaches to Ideological and Political Education in College English Teaching Practice,” Ability And Wisdom, Changchun, No. 36, pp. 18+20, December 2018. (In Chinese)

[4] Hu Jun, "A Study on the Path of Integrating the Idea of 'Ideological and Political Education through Curriculum' into College Foreign Language Courses," Communication of Vocational Education, Changzhou, No. 2, pp. 30-34, January 2019. (In Chinese)

[5] Shi Yujiao. "Exploration into the Teaching Reform of 'Ideological and Political Education in College English Teaching’ in Political and Law Colleges," The Party Building and Ideological Education in Schools, Wuhan, No. 8, pp. 30-32, April 2019. (In Chinese)

[6] Guo Zhibin. "Research on the Realization Path of Ideological and Political Teaching in College English Classroom in Local Colleges and Universities,” Wuhan, The Guide of Science \& Education, No. 8, pp. 7071, August 2019. (In Chinese)

[7] Chen Hongmei, "Exploration into the Mode of "Ideological and Political Education in College English Teaching',” Think Tank Era, Taiyuan, No. 51, pp. 17+19, December 2019. (In Chinese)

This work is supported by the Teaching Reform Project of Guangxi Higher Education (Grant No. 2013JGB152, 2016JGB223, 2018JGB177), Basic Scientific Research Ability Improvement Project for Young and Middle-aged Teachers of Guangxi’s University (Grant No. 2019KY0243), 2018 National Innovation and Entrepreneurship training Project for College and University students (Grant No. 201810595027), the Teaching Reform Project of College of Foreign Studies of GUET "Research and Practice of Ideological and Political Education in Foreign Language Teaching” and the Planning Project of Guangxi Education Sciences "Research on the longterm mechanism and implementation path of Guangxi minority culture inheritance education through cooperation between University and Secondary Vocational School”

\section{REFERENCES}

[1] He Fang and Du Ning, "Effective Approaches to Integrating Ideological and Political Education into College English Language Teaching in City-based, Application-oriented Universities,” Journal of Beijing Union University, Beijing, vol. 32, pp. 6-10, April 2018. (In Chinese)

[2] Li Ping, Wang Yuliang, Wu Meiyu and Wang Xiaohong. "Feasibility Study on the Implementation of 'Integration of Ideological and Political Education in Other Courses' in 'College English' Course,” Journal of Huaihai Institute of Technology (Humanities \& Social Sciences Edition), Huaihai, vol. 16, pp. 137-140, October 2018. (In Chinese)
[8] Wen Xieri and Li Chunying, "Design and Practice of Ideological and Political Education in College English Teaching,” Beijing, Education Modernization, No. 19, pp. 208-209, March 2019. (In Chinese)

[9] Wang Dan, "In the New Era, The Group Teaching Mode of Graduate Students' Ideological and Political Courses in Foreign Language Colleges Is Adopted Innovative research - A Case Study of the Theory and Practice of Socialism with Chinese Characteristics," Education Teaching Forum, Shijiazhuang, No. 14, pp. 226-227, April 2019. (In Chinese)

[10] Yang Gaoyun and Luo Manlin, “Ideological and Political Teaching Education Integrated into 'College English' Teaching Based on Situational Cognitive Learning Theory,” Journal of Yueyang Vocational and Technical College, Yueyang, vol. 34, pp. 57-59, July 2019. (In Chinese)

[11] Zhang Yuling. “On Ideological and Political Education in College English Teaching,” Chinese \& Foreign Entrepreneurs, Harbin, No. 24, pp. 171, August 2019. (In Chinese)

[12] Wang Shuang, "Exploration into the Combination of Ideological and Political Education and College English Teaching- Taking Hubei University of Arts and Technology as an Example,” [J]. Think Tank Era, Taiyuan, No. 43, pp. 183-184, October 2019. (In Chinese)

[13] Zhao Mingqi. "Exploration into the Combination of Ideological and Political Education and Foreign Language teaching - Taking Shanghai Foreign Studies University as an Example," Shixiang Zhengzhike Yanjiu, Shanghai, No. 2, pp. 43-46+42, December 2015. (In Chinese)

[14] Guo Wei and Wang Cong. “Construction of 'Five-in-one' Ideological and Political System in Foreign Language Teaching in Private Colleges and Universities,” Education Teaching Forum, Shijiazhuang, No. 42, pp. 36-37, October 2019. (In Chinese) 